Article

\title{
Preliminary Analysis of the Diet of Triturus carnifex and Pollution in Mountain Karst Ponds in Central Apennines
}

\author{
Mattia Iannella ${ }^{1}\left(\mathbb{D}\right.$, Giulia Console ${ }^{1, *}$, Paola $D^{\prime}$ Alessandro ${ }^{1}$, Francesco Cerasoli ${ }^{1}$ D, \\ Cristina Mantoni ${ }^{1}$, Fabrizio Ruggieri ${ }^{2} \mathbb{D}$, Francesca Di Donato ${ }^{2}$ and Maurizio Biondi ${ }^{1}$ \\ 1 Department of Life, Health and Environmental Sciences, Environmental Sciences Sect., \\ University of L'Aquila, Via Vetoio, Coppito, 67100 L'Aquila, Italy; mattia.iannella@univaq.it (M.I.); \\ paola.dalessandro@univaq.it (P.D.); francesco.cerasoli@univaq.it (F.C.); \\ cristina.mantoni@graduate.univaq.it (C.M.); maurizio.biondi@univaq.it (M.B.) \\ 2 Department of Physical and Chemical Sciences (DSFC), University of L'Aquila, Via Vetoio, Coppito, \\ 67100 L'Aquila, Italy; fabrizio.ruggieri@univaq.it (F.R.); francesca.didonato3@graduate.univaq.it (F.D.D.) \\ * Correspondence: giulia.console@graduate.univaq.it
}

Received: 29 October 2019; Accepted: 18 December 2019; Published: 20 December 2019

\begin{abstract}
Mountain karst ponds are sensitive environments, hosting complex trophic networks where amphibians play a major role, often as top predators. The diet of the Italian crested newt (Triturus carnifex) is still poorly known for populations occupying mountain karst ponds. These are traditionally used as livestock's watering points, leading to water pollution due to excreta and wading behavior. The aim of this paper is to understand the relationship between T. carnifex diet composition, assessed through the stomach flushing technique, and physical and chemical characteristics in mountain ponds, focusing on parameters altered by livestock pressure, such as ammonium concentration and dissolved oxygen. The high diversity of prey items found within the newts' gut contents confirms the generalist diet even in mountain ponds. The number of prey taxa, their relative abundance and Shannon-Wiener diversity index show variations among the sampled sites, related to livestock organic pollution. Moreover, we report the very first European records of microplastic items in amphibians' stomach content, which also represent the first evidence for Caudata worldwide. Our findings suggest that livestock pressure directly influences T. carnifex diet and highlight that the emerging issue of plastics is a threat even in remote high-altitude environments.
\end{abstract}

Keywords: diet; Triturus carnifex; mountain karst ponds; pollution; microplastics

\section{Introduction}

High-altitude ecosystems are nowadays more and more studied because of their susceptibility to ongoing climate change and habitat loss [1-3]. Many species have been proven to shift their ranges to higher altitudes [4-6] or, when the habitat does not permit these migrations, to possibly go extinct [7-9].

Karst mountain ponds are sensitive water bodies because of their exposure to several highly variable environmental factors. They are subject to seasonal snow coverage, noticeable daily and annual thermal excursion, UV-radiation and water-level changes [10-13]. As a result, the biotic component is often unique as well, showing adaptations to temperature fluctuation, long diapause or hibernation and short breeding phenology [14-16]. The species belonging to these animal communities are often of conservation concern, because of their specialization to mountain environments and to low connectivity among ponds [10,17].

In the Apennines, ponds are usually located within grasslands of karstic plateaus, and are traditionally used as watering points for livestock [18-20]. Therefore, the occurrence of cattle around 
and inside the ponds determine the eutrophication of the water through the direct and indirect introduction of their excreta [21,22], as we also frequently observed during field campaigns. Even though most of these ponds fall within National and Regional Parks, they are still vulnerable and sensitive to many occurring environmental changes, because of their limited size [23,24]. Considering the alternation of turbid and clear water due to the alternative stable state of ponds [25], it is evident that the increase of non-managed livestock in ponds (especially horses and cows) determines nutrient enrichment, shifting towards turbid water conditions through sediment resuspension and alteration of chemicals, such as ammonium and oxygen concentrations [26,27]. Such physical and chemical modification affects both the macroinvertebrates and the vertebrates in ponds. In particular, the macroinvertebrate community structure changes and negatively influences the amphibians' community; this cascade effect depends on the environmental conditions of the ponds, because of a complex interaction between abiotic and biotic components [22,28,29]. Further, amphibians themselves show high sensitivity to climate [30,31], contaminants [32-34] and habitat changes [35,36].

Despite their highly threatened status [37,38] and their importance in food webs $[39,40]$, amphibians' dietary ecology in high altitude lakes or ponds has been poorly investigated so far [41,42].

In this paper, we analyze how the ponds' alteration due to dense livestock presence could affect amphibians' diet, through the diet analysis of the Italian crested newt, Triturus carnifex, at mountain sampling sites. We study this aspect, which is still little known, focusing on both livestock-used ponds of different extents and artificial waters (rainwater collection cistern and troughs), characterized by different physical and chemical water conditions, in protected areas.

We explored, through a correspondence analysis, the association between physical and chemical variables and diversity in prey taxa in ponds with different degrees of livestock pollution. We also performed multiple statistical comparisons to test possible significant differences in the variability of newts' diet between natural and artificial sites and among the single sampling sites. We further assessed the presence of human-derived pollutants, such as plastics, which possibly affect freshwater ecosystems even in high altitudes.

\section{Materials and Methods}

\subsection{Target Species}

The Italian crested newt Triturus carnifex (Laurenti, 1768) was the target species of this study; it shows a disjunct distribution between the Italian and Balkan peninsulas [43]. In Italy, the species occurs from the sea level up to $1980 \mathrm{~m}$ [44]; in the Central Apennines, it reaches $1818 \mathrm{~m}$ a.s.l. in Lake Pantaniello [45,46].

The terrestrial environment preferred by the Italian crested newt ranges from deciduous beech forests to typically Mediterranean xeric meadows; the shelters must be fresh and moist, often found under downed woods, in forest litter and in the burrows of small mammals. The aquatic phase occurs in lakes, ponds, springs and puddles, preferably rich in aquatic vegetation for egg deposition.

Triturus carnifex is classified as "Near threatened" by the Italian IUCN red list, with a declining population trend [47]. The main threats are the destruction or alteration of its reproductive sites at different levels, the shift to intensive agricultural practices, and climate change, which often leads to the desiccation of their preferred habitats [48-50].

\subsection{Study Area}

The study area included the Central Apennines' mountain karst plains (900-1700 m a.s.l.) (Figure 1), characterized by a scarcity of surface water. In this area, we selected 9 natural and artificial sampling sites, classified as ponds, troughs and a cistern; all of them fell within two protected areas, the Gran Sasso and Monti della Laga National Park and the Sirente Velino Regional Park. In the former, the ponds named Fossetta (two neighboring ponds, coded as GSA and GSB), Fossa di Paganica (GSC) and Racollo (GSD) were studied. In the latter, the Tempra pond (SVA), the Piane di Iano pond (SVB), the 
Pagliare di Tione no-roof rainwater collection cistern, hereafter named only "cistern" (SVC), the Piano Canale (SVD) and Fonte dell'Acqua (SVE) troughs were sampled. Relevant pieces of information about the sampling sites are reported in Table 1.

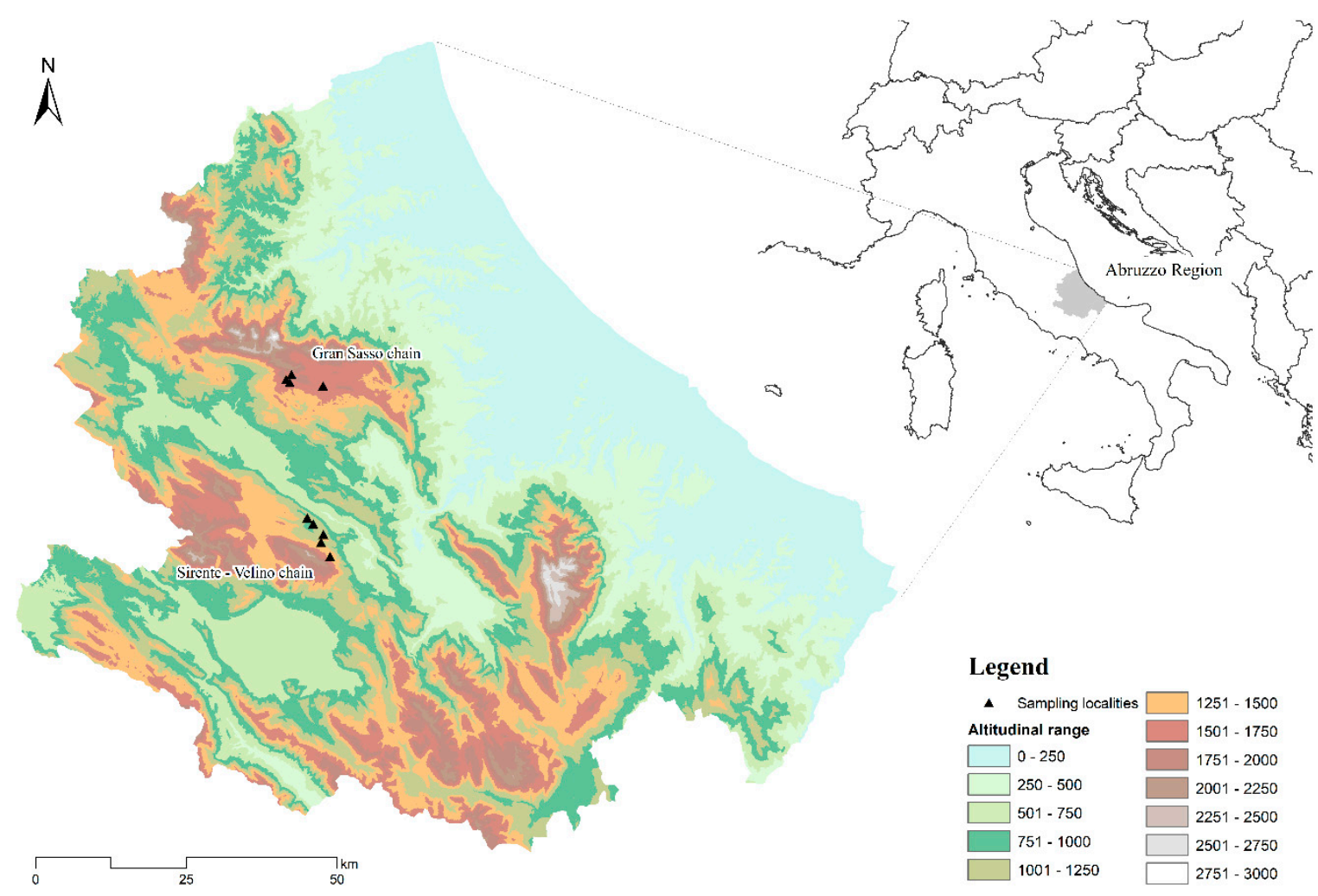

Figure 1. Study area with altitude classes and sampling localities (black triangles).

Table 1. Sampling sites considered in the analyses and the corresponding geographic information.

\begin{tabular}{cccccccc}
\hline Name & Code & Type & Area $\left(\mathbf{m}^{2}\right)$ & $\begin{array}{c}\text { Max. } \\
\text { Depth }(\mathbf{m})\end{array}$ & Latitude & Longitude & $\begin{array}{c}\text { Elevation } \\
(\mathbf{m} \text { a.s.1.) }\end{array}$ \\
\hline Fossetta A & GSA & Pond & 1870 & 1.2 & $42^{\circ} 24^{\prime} 17^{\prime \prime} \mathrm{N}$ & $13^{\circ} 35^{\prime} 14^{\prime \prime} \mathrm{E}$ & 1658 \\
Fossetta B & GSB & Pond & 358 & 1.2 & $42^{\circ} 24^{\prime} 19^{\prime \prime} \mathrm{N}$ & $13^{\circ} 35^{\prime} 13^{\prime \prime} \mathrm{E}$ & 1658 \\
Fossa di Paganica & GSC & Pond & 4500 & 1.5 & $42^{\circ} 24^{\prime} 55^{\prime \prime} \mathrm{N}$ & $13^{\circ} 39^{\prime} 27^{\prime \prime} \mathrm{E}$ & 1680 \\
Racollo & GSD & Pond & 7000 & 0.8 & $42^{\circ} 23^{\prime} 37^{\prime \prime} \mathrm{N}$ & $13^{\circ} 39^{\prime} 27^{\prime \prime} \mathrm{E}$ & 1570 \\
Tempra & SVA & Pond & 870 & 1.5 & $42^{\circ} 10^{\prime} 22^{\prime \prime} \mathrm{N}$ & $13^{\circ} 38^{\prime} 30^{\prime \prime} \mathrm{E}$ & 1183 \\
Piane di Iano & SVB & Pond & 780 & 1.2 & $42^{\circ} 11^{\prime} 21^{\prime \prime} \mathrm{N}$ & $13^{\circ} 37^{\prime} 22^{\prime \prime} \mathrm{E}$ & 960 \\
Pagliare di Tione & SVC & Cistern & 125 & 2.5 & $42^{\circ} 11^{\prime} 55^{\prime \prime} \mathrm{N}$ & $13^{\circ} 36^{\prime} 41^{\prime \prime} \mathrm{E}$ & 1080 \\
Piano Canale & SVD & Trough & 15 & 0.5 & $42^{\circ} 08^{\prime} 25^{\prime \prime} \mathrm{N}$ & $13^{\circ} 39^{\prime} 17^{\prime \prime} \mathrm{E}$ & 1342 \\
Fonte dell' Acqua & SVE & Trough & 26 & 0.5 & $42^{\circ} 08^{\prime} 21^{\prime \prime} \mathrm{N}$ & $13^{\circ} 39^{\prime} 10^{\prime \prime} \mathrm{E}$ & 1167 \\
\hline
\end{tabular}

The GSA, GSB, GSD and SVB ponds show remarkable water level variations during summer; they are characterized by turbid waters (because of the silty bottom) and scarce vegetation (mainly composed by Potamogeton, Ceratophyllum and Myriophyllum) due to the constant presence of livestock (sheep, cows and horses), which enter the ponds for some meters from the banks (Figure 2). On the contrary, GSC and SVA show clearer waters, probably due to the wide extent (and the gravel bottom) of the former and due to the low livestock frequentation of the latter. In all these ponds, water is supplied only from snow melting and rainfall. SVC is not used by livestock as a watering point because of its limited accessibility due to perimeter walls; it has clear water and abundant aquatic vegetation. Finally, SVD and SVE show clear water and aquatic vegetation (including algae) as well; they are used as watering points, but livestock does not enter them. 

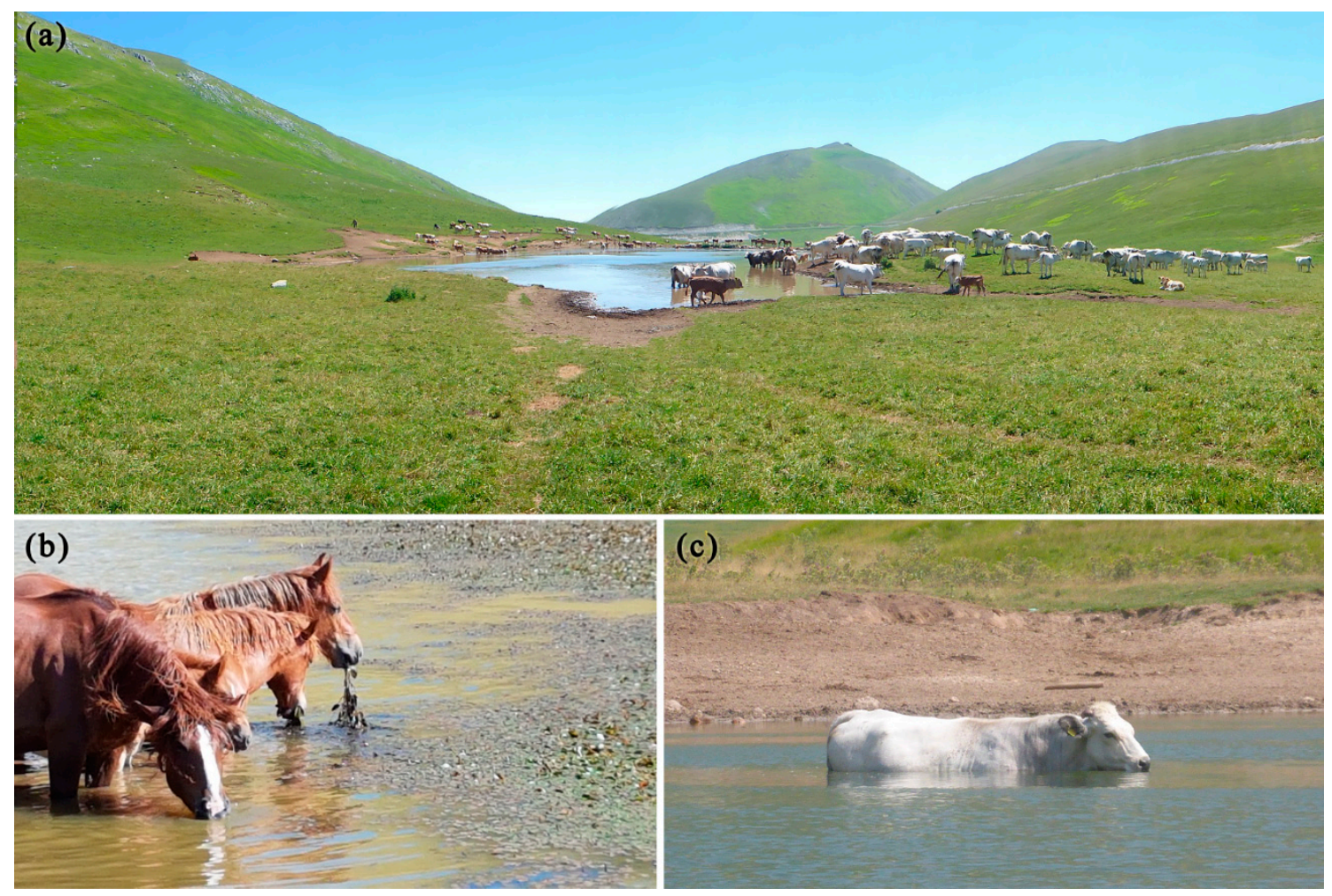

Figure 2. Livestock near Fossa di Paganica pond, GSC (a); horses grazing aquatic plants (b) and cow cooling off during summer (c) in the Fossetta pond, GSA.

\subsection{Sampling Methods}

Newts (excluding larvae) were sampled starting from 2015 to 2019 (June-September, following the aquatic phase of the target species), employing both active and passive sampling methods. Dip netting sessions were performed, following a circular transect to cover the entire pond's perimeter. Funnel traps were also used as passive capture method, leaving them in the sampling sites for a 12-h period. The captured newts were stomach flushed using all the necessary equipment as described in [51]; the stomach contents were stored in Eppendorf safe-lock tubes with 70\% ethanol.

A multi-parametric probe Eutech PD650 (EUTECH Instruments, Singapore, Singapore) was used to measure $\mathrm{pH}$, dissolved oxygen $(\mathrm{DO}$ in $\mathrm{mg} / \mathrm{L})$, redox potential $(\mathrm{mV})$ and the possible presence of ammonium $\left(\mathrm{NH}_{4}{ }^{+}\right.$concentration, $\left.\mathrm{mg} / \mathrm{L}\right)$, resulting from livestock excreta directly released within the ponds (or nearby the corresponding banks). All of the parameters were measured once for each sampling session.

\subsection{Diet Analysis}

The prey items were identified at the lowest taxon allowed by the level of digestion, generally as orders.

The sampled newts for each sampling site, the number of different prey groups and the total number of prey items found within the stomach contents of each newt are reported in Supplementary Material Table S1.

Diversification of predated taxa was calculated for each sampled newt within each sampling site through the Shannon-Wiener diversity index $\left(\mathrm{H}^{\prime}\right)$, by means of the 'diversity' function of the 'vegan' [52] package in R [53]. The resulting H' values are reported in Supplementary Material Table S1.

Appropriate statistical tests were conducted in $\mathrm{R}$ to check for potential discrepancies in the diversification of prey groups among the sampling sites, as well as among the types of sampling sites 
(i.e., ponds, cistern and troughs) and their "class" (i.e., natural, comprising the ponds, and artificial, including the cistern and the troughs).

A Shapiro-Wilk test and QQ plots were used to check the normality of the residuals from a linear model built considering the $\mathrm{H}^{\prime}$ index as the response variable and the three above-mentioned grouping factors as covariates. Levene tests were performed to check homoscedasticity across the levels of the three grouping arrangements. Kruskall-Wallis tests were conducted to assess the significance of the considered grouping factors.

Subsequently, multiple pairwise Wilcoxon Rank Sum tests were conducted, using the 'pairwise.wilcox.test' function in R [53] with the Benjamini and Hochberg $p$-value adjustment method, to investigate differences among the single levels of the grouping factor(s) resulting as significant.

Moreover, we considered for each site the relative percentages of the different prey taxa per "average newt" (i.e., the ratio between the number of prey items, for each taxon, and the number of captured newts).

Correspondence analysis was performed through the 'ca' package [54] in RStudio [53], using both chemical parameters and relative prey abundance for each sampling sites as variables.

Together with prey items and other materials (e.g., parts of plants and sediments), we unexpectedly found microplastics in some stomach contents. All microplastics were observed and measured through a Leica M205C (Leica Microsystems, Wetzlar, Germany) binocular microscope. Photomicrographs were taken using a Leica DFC500 camera and the Zerene Stacker software (Zerene Systems LLC, Richland, WA, USA) version 1.04 .

\section{Results}

The stomach contents of 239 Italian crested newts were collected from the nine sampling sites. The number of sampled newts and the total number of prey items for the different prey groups (for each site) are reported in Supplementary Material Tables S1 and S2.

Prey items were counted and classified in 19 different taxa, namely Crustacea (4750 prey items), Diptera (1800), Haplotaxida (328), Odonata (220), Hemiptera (191), Mollusca (135), Ephemeroptera (75), Coleoptera (53), Araneae (35), Acarina (17), Hymenoptera (13), Dermaptera (five), Caudata (four), Trichoptera (three), Tricladida (three), Lepidoptera (two), Julida (two), Neuroptera (one) and Mermithida (one). A total of 641 items could not be determined, due to the high level of deterioration; 161 fragments of plants, 93 particles of inorganic sediments probably deriving from the bottom, 59 microplastic items in the form of fibres, splinters and other undeterminable fragments were also found.

Crustacea (among which 47\% were Ostracoda, 33\% Branchiopoda and 19\% Maxillopoda) and Diptera (among which 81\% were Chironomidae and 9\% Culicidae) showed the highest frequencies per average newt in almost all the sampling sites, with Crustacea exceeding $85 \%$ of the total prey items in GSD and SVB; differently, the highest Diptera frequency is found in SVA (Figure 3). GSC showed the highest number of taxa (14) per average newt, followed by SVD (13) and an equal number for SVA and SVE (11); the remaining five sampling sites showed a total number of prey taxa $\leq 10(\mathrm{GSA}=10$, $\mathrm{SVC}=10, \mathrm{GSD}=8, \mathrm{GSB}=7, \mathrm{SVB}=6$ )

With respect to the analyses performed to assess the level of diversification within the diet of the single newts among the sampling sites, the performed Shapiro-Wilk test $\left(\mathrm{W}=0.95, p=4.49 \times 10^{-7}\right)$ and the inspected QQ plot led us to reject the hypothesis of the normality of the residuals from the linear model built upon the $\mathrm{H}^{\prime}$ index, while the Levene tests did not reject homoscedasticity for the sampling site $(\mathrm{F}=0.97, p=0.46)$, site type $(\mathrm{F}=1.35, p=0.26)$ and site class $(\mathrm{F}=0.06, p=0.80)$ grouping factors. 


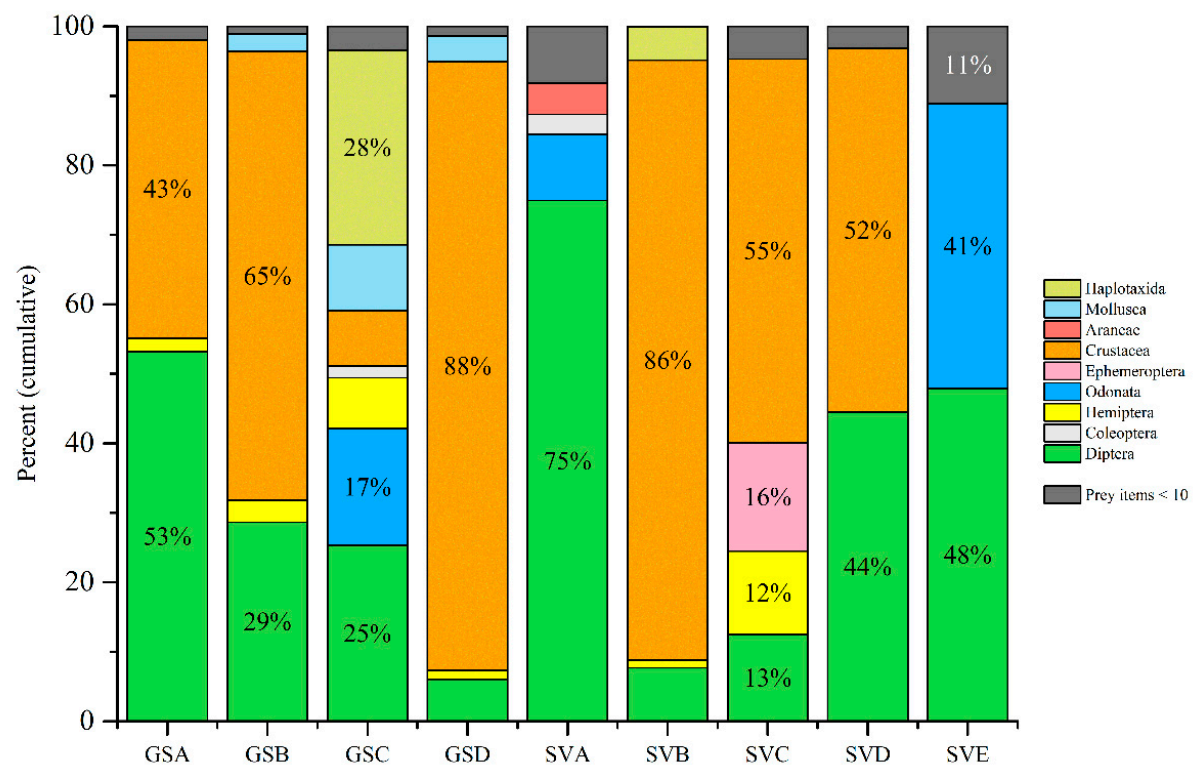

Figure 3. Frequency of prey items (taxa) for each sampled site. Taxa $<10$ prey items were aggregated into a single class (grey); percentages $<10 \%$ are not reported within the figure for graphical purposes.

Given the normality assumption was not met, a Kruskall-Wallis test was used to check the significance of the three grouping factors-significant differences in the means of the single levels resulted in only considering the sampling sites as a grouping factor $\left(\chi^{2}=18.01, \mathrm{df}=8, p=0.02\right)$.

From the Wilcoxon Rank Sum tests successively performed on this grouping factor, GSB presented as significantly more diversified in terms of taxa predated by the single newts with respect to SVE $(p=0.04)$; it is also worth noticing the low median $\mathrm{H}^{\prime}$ value of GSA, GSD, SVB and SVE with respect to the remaining sampling sites (Figure $4 a$ ).
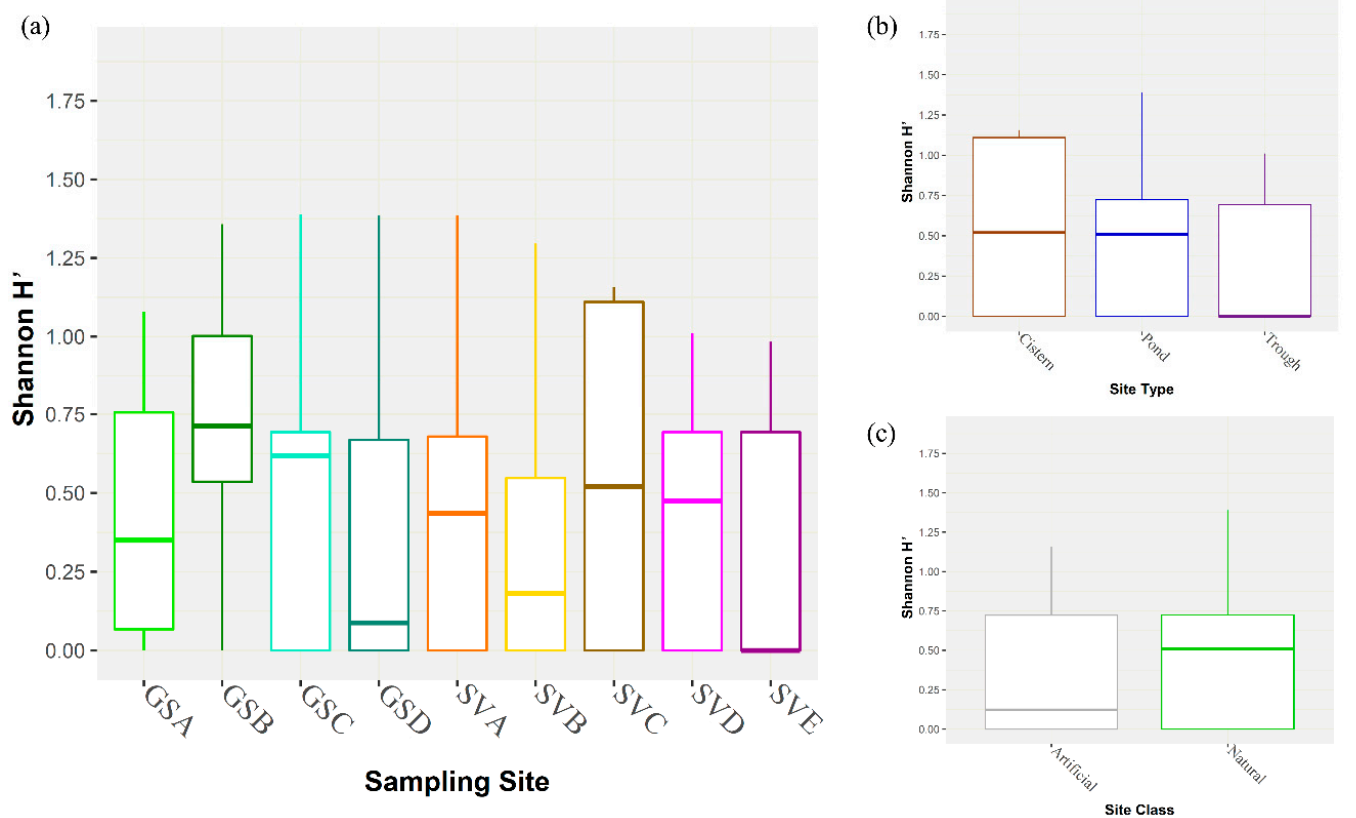

Figure 4. Boxplots of Shannon-Wiener $\mathrm{H}^{\prime}$ index values across sampling sites (a), site types (b), and site classes (c).

Notwithstanding, the site type $\left(\chi^{2}=4.29, \mathrm{df}=2, p=0.12\right)$ and site class $\left(\chi^{2}=2.32, \mathrm{df}=8\right.$, $p=0.13$ ) were shown to be non-significant grouping factors by the Kruskall-Wallis tests, considering 
the differences among the levels of these two factors emerging from boxplots in Figure $4 \mathrm{~b}, \mathrm{c}$, single Mann-Whitney $U$ tests were performed between natural and artificial sites, and among the three site types.

With respect to site class, the diets of the single newts within natural sites could be considered to be more diversified than in artificial ones $(U=5798.5, p=0.06$, alternative $=$ 'greater') under a less constraining 0.1 threshold for the $p$-value; differently, considering site types, diets of the single newts in ponds were seen to be significantly richer than in (averages across the replicates) troughs $(\mathrm{U}=4781, p=0.02$, alternative $=$ 'greater' $)$, while no significant pattern emerged for the other two pairs (i.e., ponds-cistern and cistern-troughs).

The chemical parameters measured for each sampling site (averages across the replicates) are reported in Table 2. GSA, GSB, GSD and SVB show very low values of dissolved oxygen, along with relatively high values of ammonium (up to $0.26 \mathrm{mg} / \mathrm{L}$ in SVB), leading to classify them as "low water quality sites".

Table 2. Chemical parameters measured for each sampling site.

\begin{tabular}{|c|c|c|c|c|c|}
\hline Name & Code & $\mathrm{pH}$ & $\begin{array}{c}\text { Redox } \\
\text { Potential }(\mathrm{mV})\end{array}$ & $\begin{array}{c}\text { DO (mg/L) } \\
\left(\mathrm{DO}\left(\% \text { sat), Temp. }\left({ }^{\circ} \mathrm{C}\right)\right)\right.\end{array}$ & $\mathrm{NH}_{4}{ }^{+}(\mathrm{mg} / \mathrm{L})$ \\
\hline Fossetta A & GSA & 7.3 & -6.9 & $3.0\left(38 \%, 20.8^{\circ} \mathrm{C}\right)$ & 0.12 \\
\hline Fossetta B & GSB & 7.6 & -17.7 & $3.6\left(47 \%, 21.1^{\circ} \mathrm{C}\right)$ & 0.17 \\
\hline Fossa di Paganica & GSC & 8.3 & 38.1 & $4.5\left(62 \%, 24.0^{\circ} \mathrm{C}\right)$ & 0.00 \\
\hline Racollo & GSD & 7.6 & -7.9 & $2.3\left(32 \%, 23.2^{\circ} \mathrm{C}\right)$ & 0.03 \\
\hline Tempra & SVA & 9.5 & -5.1 & $7.0\left(90 \%, 24.2^{\circ} \mathrm{C}\right)$ & 0.06 \\
\hline Piane di Iano & SVB & 7.5 & -28.7 & $3.7\left(45 \%, 17.9^{\circ} \mathrm{C}\right)$ & 0.26 \\
\hline Pagliare di Tione & SVC & 8.5 & 16.2 & $7.2\left(87 \%, 21.4^{\circ} \mathrm{C}\right)$ & 0.00 \\
\hline Piano Canale & SVD & 8.1 & 27.2 & $7.8\left(96 \%, 20.3^{\circ} \mathrm{C}\right)$ & 0.00 \\
\hline Fonte dell'Acqua & SVE & 7.9 & 24.7 & $7.4\left(93 \%, 23.4^{\circ} \mathrm{C}\right)$ & 0.00 \\
\hline
\end{tabular}

SVA and GSC can be classified as "halfway sites", while SVC, SVD and SVE, which represent the artificial sites, could be grouped as "high water quality sites" (Table 2).

The correspondence analysis (Figure 5) resulted in a neat prevalence of Dim 1 (80.4\%) along which natural sites (GSA, GSB, GSD, SVA and SVB) and artificial ones (SVC, SVD and SVE) are clearly separated, except for the GSC pond, which groups with the latter. Ammonium is distant from DO and redox potential and placed near to the ponds group; differently, $\mathrm{pH}$ does not seem to form any relevant group with the other variables. Mollusca, Crustacea, Hemiptera, Coleoptera and Diptera are placed in the negative portion of Dim 1, near the ponds group; on the contrary, Odonata, Trichoptera and Caudata are the main taxa placed close to the artificial sites. Tricladida, Mermithida, Haplotaxida, Julida, Dermaptera, Ephemeroptera and Hymenoptera are located between the two groups of sampling sites, in proximity to the artificial sites. Acarina, Araneae and Lepidoptera are distant from both the ponds and artificial sites groups, while Neuroptera is completely separated along the positive portion of the Dim 2 (not shown), probably due to their little contribution in diet diversity.

Microplastics were found in the stomach contents of newts inhabiting four sampling sites, namely GSC, GSD, SVD and SVE. A sample for each type of microplastic found is represented in Figure 6. Two net-like plastic fragments were found in the stomach flush of a newt sampled in GSD, measuring $3.7 \mathrm{~mm}$ and $3.1 \mathrm{~mm}$, respectively (Figure 6a). Two textile-like fibres (out of many others found in all the sampling sites) are shown in Figure 6b, measuring $1.8 \mathrm{~mm}$ (blue) and $1.2 \mathrm{~mm}$ (red). Finally, a blue microplastic fragment $(1.44 \mathrm{~mm}$ in size), was found in the stomach contents of a newt sampled in the SVE trough along with a little $(0.1 \mathrm{~mm})$ yellow fragment (Figure $6 \mathrm{c}$ ). 


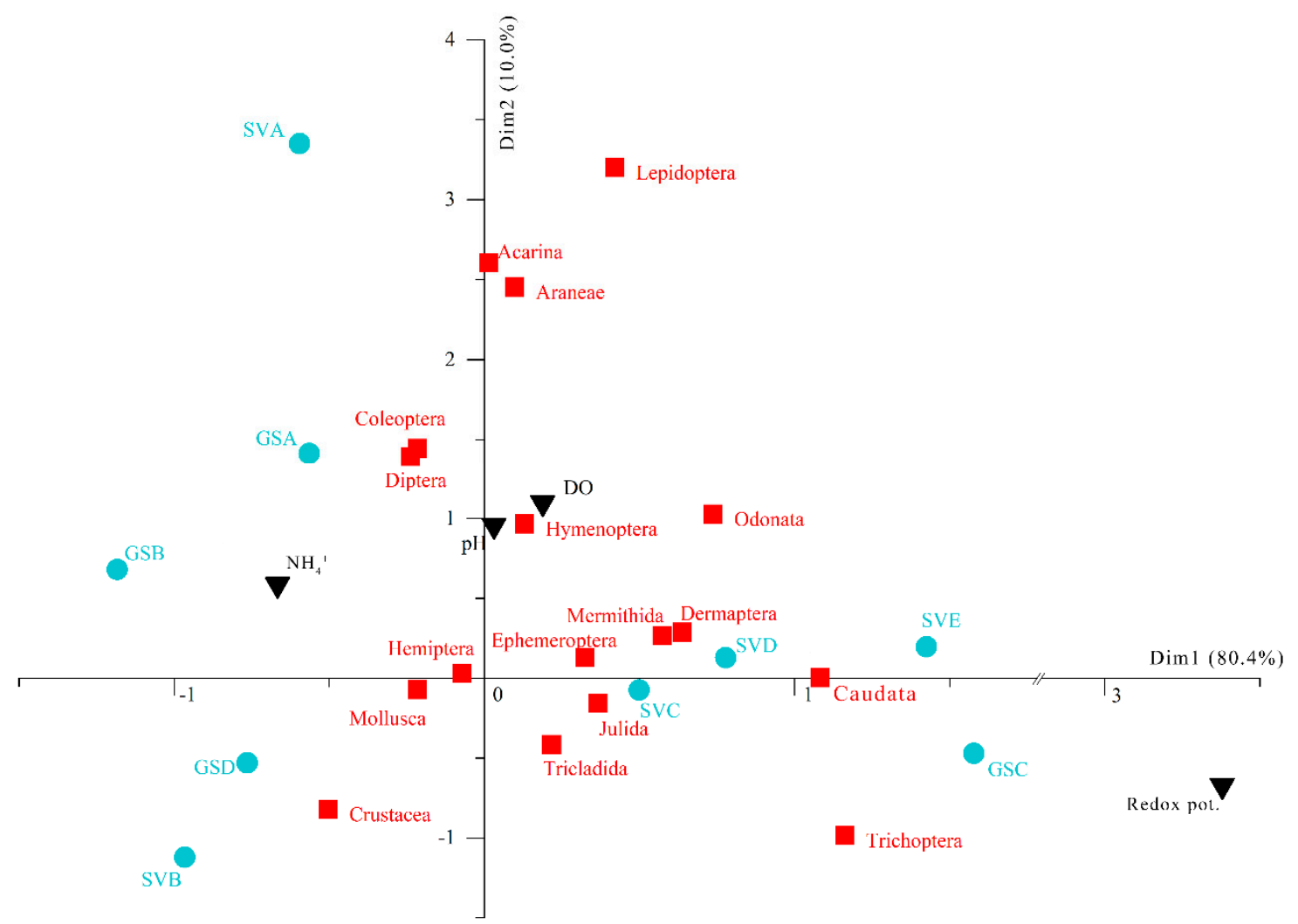

Figure 5. Correspondence analysis for both prey items and chemical parameters measured in all sampling sites. Blue circles: sampling sites, red squares: prey taxa and black triangles: physical and chemical parameters.

To characterize these items, ATR-FT-IR analyses were carried out using a Perkin Elmer (USA) Spectrum Two ${ }^{\mathrm{TM}}$ FTIR (PerkinElmer, Waltham, MA, USA) instrument equipped with the Attenuated Total Reflectance (ATR) accessory with a single bounce diamond crystal. The microplastics were analyzed at a $1 \mathrm{~cm}^{-1}$ resolution within the $4000-400 \mathrm{~cm}^{-1}$ range, with air used for the background spectrum. A consistent force was applied using the pressure monitoring system integrated with the instrument to maximize the spectrum intensity; the optimal number of scans was determined by collecting the spectra of the plastic fragments. An increase in the quality of the signal-to-noise ratio between 10 and 50 scans at a spectral resolution of $1 \mathrm{~cm}^{-1}$ was observed. After 50 scans, the improvement in spectral quality was less evident, thus, all samples were collected at 50 scans.

Analyses by ATR-FT-IR spectroscopy enabled the identification of microplastics by detecting absorbance bands. In Figure 7, the IR spectra of a fragment of polyethylene resulting from the analysis of the blue item pictured in Figure $6 \mathrm{c}$ are reported, corresponding to the bands of absorbance intrinsic of the stretching of $\mathrm{C}-\mathrm{H}\left(3000-2770 \mathrm{~cm}^{-1}\right)$ and the bending of $\mathrm{C}-\mathrm{H}\left(1500-1450 \mathrm{~cm}^{-1}\right)$ bonds. Additionally, ATR-FT-IR measurements enabled the detection of bands attributed to the scissoring of $\mathrm{C}-\mathrm{H}$ bonds $\left(750-700 \mathrm{~cm}^{-1}\right)$.

The IR analysis of the fragments pictured in Figure 6a shows the characteristic bands of a medical pressure-sensitive adhesive (spectrum in Supplementary Material Figure S1a). The fibres reported in Figure $6 \mathrm{~b}$ are probably part of mountain technical clothes. The analysis of the corresponding IR spectrum (Supplementary Material Figure S1b) shows the presence of the typical bands of polyacrylic polymers, although the signal-to-noise ratio is moderately low.

Finally, the chop of Figure $6 \mathrm{c}$ is likely to be a part of a plastic bottle cap, considering its polyethylene composition revealed by the IR spectra. 
(a)
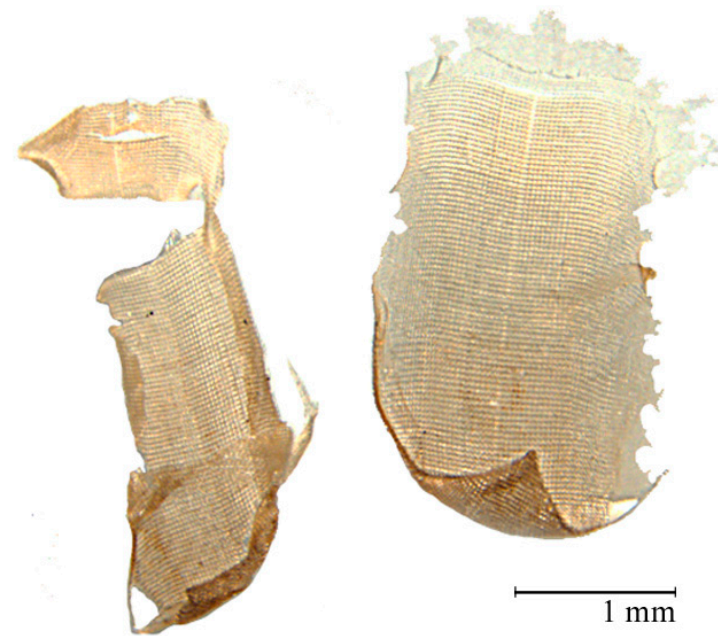

(b)

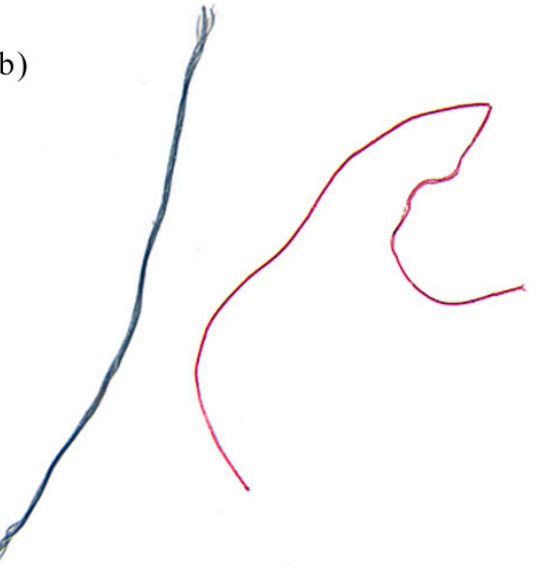

(c)

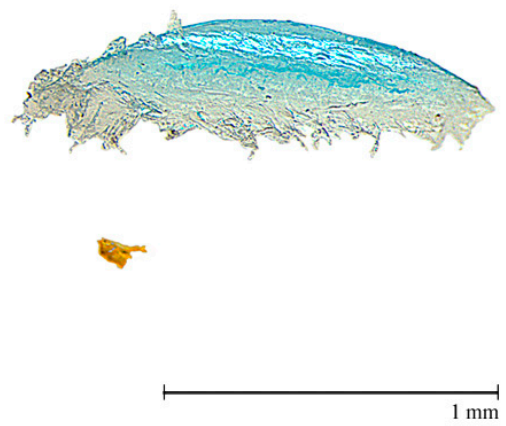

Figure 6. Microplastics found within Triturus carnifex stomach contents. (a) the biggest fragments found, probably deriving from a medical patch; (b) blue and red fibres, probably deriving from mountain clothes; (c) chop, probably deriving from a plastic bottle and very small yellow fragment (bottom) from an undeterminable origin.

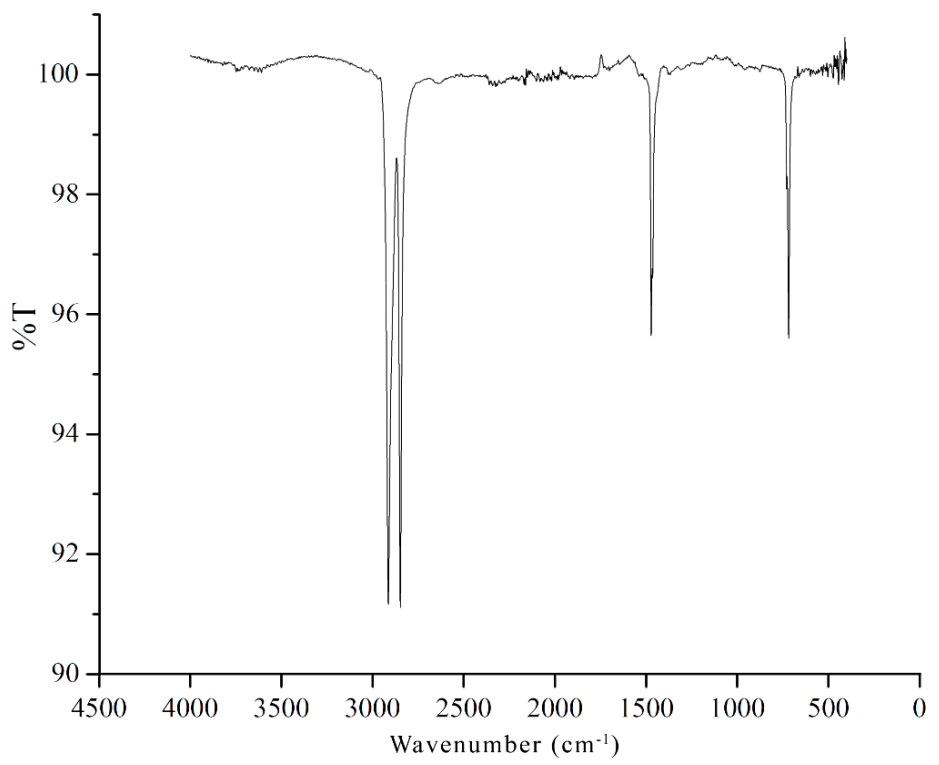

Figure 7. IR spectrum of the polyethylene chop (displayed in Figure 6c, above) found within an Italian crested newt's stomach contents. 


\section{Discussion}

The Italian crested newt exhibits a generalist diet $[44,55,56]$, consuming a considerable variety of preys [57]. In our samples, aquatic invertebrates presented the great majority of the collected preys; the most predated taxa were Crustacea, followed by Diptera, with a neat prevalence of small-sized prey items for both, while the others 17 taxa found in the stomach contents were less represented.

The study area has been used for centuries for grazing, and its management has been subject to national regulation for at least 100 years [58]; while in the past the studied territory was mainly pastured by sheep, nowadays cattle and horses represent the main grazers. This determines a change in grazing management, since usually only sheep are looked after by the shepherd during the whole day (personal field observations). The differences in the chemical and physical conditions observed in the sampled sites may be the direct consequence of such kind of pasture management: in fact, while sheep do not usually wade the ponds, cows and horses are frequently observed in them. Thus, ponds are subject to livestock wading and defecation, determining an alteration of water quality, while drinking troughs or tanks does not usually undergo these pressures [29,59]. This could explain the notable differences between the natural sampled sites and the artificial ones, in terms of abiotic conditions.

The correspondence analysis permitted us to segregate two main groups. Sites showing good physical and chemical parameters (i.e., the three artificial sites and the GSC pond) are associated along the positive half of Dim 1 with taxa with narrow ecological tolerances to disturbance and organic pollution (e.g., Odonata, Ephemeroptera and Trichoptera). Differently, GSD and SVB are placed on the negative portion of Dim 1 and Dim 2 and are mainly associated with Crustacea, which showed predominance in the diet of newts from these sites, leading to low prey diversity (Figures 3 and $4 \mathrm{a}$ ). These two sites are part of a larger group comprising also GSA and GSB (as shown by the correspondence plot), in which all sites are associated with ammonium, probably reflecting the ease of livestock wading in these ponds. SVA, which shows low ammonium and high DO concentrations when compared to the aforementioned sites, is distant from this group along Dim 2; this can be explained by the low livestock density around this site (personal observation).

The controversial impact of grazing on amphibians' communities is still debated, as reviewed by Howell, Mothes, Clements, Catania, Rothermel and Searcy [29]; some studies highlighted the negative effects of grazing on amphibians, e.g., [60,61], while others documented a positive or intermediate response, due to the species-specific requirements of the target amphibians [62-64].

Based on our research, ponds, which represent typical habitats for the newts in grasslands of karst plains and show high biodiversity in uncontaminated conditions [13], are negatively influenced by livestock pressure, especially when they can be easily waded. Indeed, we found livestock contamination altering the chemical and physical water parameters in ponds (e.g., low redox potential, high ammonium and low DO); this can be related to the absence of highly sensitive taxa and the consequent low number of different predated taxa per site.

Another important aspect is that the only water supply for these ponds derives from snow melting and rain, resulting in a low rate of water replacement, especially during late summer, when the pasture pressure increases.

On the other hand, the artificial sampling sites, notwithstanding their small extent, present a high number of prey taxa, probably due to the constant water flow, which positively contributes to the high quality of water in these sites. This is further confirmed by the presence of some taxa which exhibit a reduced tolerance to the disturbances found in ponds, as also shown by the correspondence analysis.

Fossa di Paganica (GSC) is the only pond which does not follow this trend, showing conditions similar to the artificial sampling sites; in fact, it presents the highest number of prey taxa among all sites, and good chemical parameters. This could be explained by the large dimensions of the pond, which allow for the buffering of the negative effects of cattle and horses wading and defecating. Furthermore, the diffused presence of macrophytes found in GSC could favour macroinvertebrate diversity, as already observed in other karst ponds [65]. This is reflected by the high number of prey taxa found in this site, which could anyway be an underestimation of the total macroinvertebrate diversity. 
Notwithstanding the evidence of livestock contamination of ponds and the corresponding influence on the number of prey taxa, the analysis of the Shannon $\mathrm{H}^{\prime}$ variations among the sites showed that prey diversification for each newt is occasionally high if compared to the number of prey taxa per sampling site (e.g., GSB and SVA, see Figure 4a).

Previous studies showed that the low diversity of available prey may hamper larval development, due to low intake of dietary antioxidants $[66,67]$ leading to reduced immune response capability and mass growth [68]. Thus, we speculate that newts, also considering their generalist diet, may be led to diversify their preys as much as possible, to integrate a possible lack of nutrients and avoid the negative effects mentioned before.

Furthermore, amphibian feeding is also conditioned by interspecific competition [69], which can be changed by the noticeable disequilibria found in most of the sampled sites, considering the absence of invertebrate predators (sometimes also acting as preys), such as Coleoptera, Hemiptera and Odonata.

In this work, we present the first European record of microplastics in amphibians' stomach contents and the first one ever recorded for Caudata.

While several studies about microplastics in marine ecosystems have been published in recent decades [70], field studies examining their presence in freshwater ecosystems started only recently [71]. Despite both Caudata and Anuran being among the most threatened animal groups worldwide, the only papers assessing the presence of microplastics in gut content referred to Anuran species [71,72]. Moreover, the previous records of microplastics in Anuran stomach contents were collected in human-altered freshwater habitats, such as farmlands surrounding river deltas [72] and plantations [71]; on the contrary, we found evidences of microplastic ingestion in scarcely populated, high-elevation territories, even covered by protected areas.

The chemical composition of the collected microplastics, emerging from the performed ATR-FT-IR spectroscopy analyses, shows that they are associated to human activities carried out in mountain environments, such as pastoralism and tourism; indeed, the majority of microplastic items are textile fibres (Figure $6 \mathrm{~b}$ ). The presence of these fibres in sampling sites may be due to waste displacement by the wind from the neighbouring roads and mountain retreats, or to livestock-related items, such as horse bridles or cow tags.

While the effects of microplastic ingestion by amphibians have been already assessed in laboratory studies with contrasting results $[73,74]$, there is no information about the potential negative impacts on amphibians' communities in freshwater habitats.

\section{Conclusions}

High-altitude environments are nowadays proven to be very sensitive to ongoing environmental changes; the alteration of their freshwater habitats leads to rapid and dramatic loss of biodiversity. While, on one hand, pasture has shaped some peculiar environments for centuries, on the other hand it may represent a serious threat if not correctly managed. Human presence has, in this case, a dual role; it may cause a loss of diversity (e.g., unmanaged pasture) but it may also lead to the persistence of amphibian populations, because of the construction of artificial watering points, which currently host highly diverse communities. This is the very first assessment of the livestock-related detrimental effects on newts' diets in mountain karstic ponds; ongoing targeted sampling campaigns will enrich the knowledge about these threats, which widely affect mountain ecosystems.

The unexpected discovery of microplastics in many stomach contents reinforces the alarm about the ubiquitous plastic pollution of natural habitats, even in high-altitude protected territories; it is thus worth conducting future targeted research about this emerging issue to properly adapt conservation strategies.

Supplementary Materials: The following are available online at http://www.mdpi.com/2073-4441/12/1/44/s1, Figure S1: IR spectra of (a) medical pressure-sensitive adhesive and (b) fibres pictured in Figure 6a,b, respectively, found within Italian crested newts' stomach contents. Table S1: Sampled newts for each sampling site, number of 
different prey groups, Shannon $\mathrm{H}^{\prime}$, and total number of prey items found within the stomach content of each newt. Table S2: Macroinvertebrates found within stomach contents for all the sampled newts within each sampling site.

Author Contributions: Conceptualization, M.I. and M.B.; methodology, M.I., G.C. and F.C.; software, M.I., G.C. and P.D.; formal analysis, G.C., C.M. and P.D.; data curation, G.C. and C.M.; chemical analyses, F.R. and F.D.D.; writing — original draft preparation, all authors; writing — review and editing, all authors; funding acquisition, M.I. and M.B. All authors have read and agreed to the published version of the manuscript.

Funding: This work was supported by the A.I.M. Project-PON R \& I 2014-2020 No. 1870582.

Acknowledgments: We are particularly thankful to the Scientific Department of Gran Sasso-Monti della Laga. National Park and to the Scientific and Naturalistic Office of the Sirente-Velino Regional Park for the technical support provided during the collection of some field data (permissions n. 0000219/15 UT-RAU-SCNZ448 and N. VII-02-02-P6213).

Conflicts of Interest: The authors declare no conflict of interest.

\section{References}

1. Rogora, M.; Frate, L.; Carranza, M.; Freppaz, M.; Stanisci, A.; Bertani, I.; Bottarin, R.; Brambilla, A.; Canullo, R.; Carbognani, M.; et al. Assessment of climate change effects on mountain ecosystems through a cross-site analysis in the Alps and Apennines. Sci. Total Environ. 2018, 624, 1429-1442. [CrossRef]

2. Dirnböck, T.; Essl, F.; Rabitsch, W. Disproportional risk for habitat loss of high-altitude endemic species under climate change. Glob. Chang. Biol. 2011, 17, 990-996. [CrossRef]

3. Brambilla, M.; Pedrini, P.; Rolando, A.; Chamberlain, D.E. Climate change will increase the potential conflict between skiing and high-elevation bird species in the Alps. J. Biogeogr. 2016, 43, 2299-2309. [CrossRef]

4. Di Musciano, M.; Carranza, M.; Frate, L.; Di Cecco, V.; Di Martino, L.; Frattaroli, A.; Stanisci, A. Distribution of plant species and dispersal traits along environmental gradients in central Mediterranean summits. Diversity 2018, 10, 58. [CrossRef]

5. Cerasoli, F.; Iannella, M.; Biondi, M. Between the hammer and the anvil: How the combined effect of global warming and the non-native common slider could threaten the European pond turtle. Manag. Biol. Invasions 2019, 10, 428. [CrossRef]

6. Chamberlain, D.; Brambilla, M.; Caprio, E.; Pedrini, P.; Rolando, A. Alpine bird distributions along elevation gradients: The consistency of climate and habitat effects across geographic regions. Oecologia 2016, 181, 1139-1150. [CrossRef] [PubMed]

7. Cerasoli, F.; Thuiller, W.; Guéguen, M.; Renaud, J.; D'Alessandro, P.; Biondi, M. The role of climate and biotic factors in shaping current distributions and potential future shifts of European Neocrepidodera (Coleoptera, Chrysomelidae). Insect Divers. Conserv. 2019. [CrossRef]

8. Brunetti, M.; Magoga, G.; Iannella, M.; Biondi, M.; Montagna, M. Phylogeography and species distribution modelling of Cryptocephalus barii (Coleoptera: Chrysomelidae): Is this alpine endemic species close to extinction? ZooKeys 2019, 856, 3. [CrossRef] [PubMed]

9. Wiens, J.J. Climate-Related local extinctions are already widespread among plant and animal species. PLoS Biol. 2016, 14. [CrossRef] [PubMed]

10. Oertli, B.; Biggs, J.; Céréghino, R.; Grillas, P.; Joly, P.; Lachavanne, J.B. Conservation and monitoring of pond biodiversity: Introduction. Aquat. Conserv. Mar. Freshw. Ecosyst. 2005, 15, 535-540. [CrossRef]

11. Niedrist, G.; Psenner, R.; Sommaruga, R. Climate warming increases vertical and seasonal water temperature differences and inter-annual variability in a mountain lake. Clim. Chang. 2018, 151, 473-490. [CrossRef]

12. Sommaruga, R. The role of solar UV radiation in the ecology of alpine lakes. J. Photochem. Photobiol. B Biol. 2001, 62, 35-42. [CrossRef]

13. Hinden, H.; Oertli, B.; Menetrey, N.; Sager, L.; Lachavanne, J.B. Alpine pond biodiversity: What are the related environmental variables? Aquat. Conserv. Mar. Freshw. Ecosyst. 2005, 15, 613-624. [CrossRef]

14. Miaud, C.; Guyetant, R.; Faber, H. Age, size, and growth of the alpine newt, Triturus alpestris (Urodela: Salamandridae), at high altitude and a review of life-history trait variation throughout its range. Herpetologica 2000, 56, 135-144.

15. Alonso, M.; Garcia-De-Lomas, J. Systematics and ecology of Linderiella baetica n. sp. (Crustacea, Branchiopoda, Anostraca, Chirocephalidae), a new species from southern Spain. Zoosystema 2009, 31, 807-828. [CrossRef] 
16. Mushet, D.M.; Euliss Jr, N.H.; Chen, Y.; Stockwell, C.A. Complex spatial dynamics maintain northern leopard frog (Lithobates pipiens) genetic diversity in a temporally varying landscape. Herpetol. Conserv. Biol. 2013, 8 , 163-175.

17. Lund, J.O.; Wissinger, S.A.; Peckarsky, B.L. Caddisfly behavioral responses to drying cues in temporary ponds: Implications for effects of climate change. Freshw. Sci. 2016, 35, 619-630. [CrossRef]

18. Catorci, A.; Gatti, R.; Vitanzi, A. Relationship between phenology and above-ground phytomass in a grassland community in central Italy. In Nature Conservation. Environmental Science and Engineering (Environmental Science); Gafta, D., Akeroyd, J., Eds.; Springer: Heidelberg, Germany, 2006; pp. 309-327.

19. Filibeck, G.; Cancellieri, L.; Sperandii, M.G.; Belonovskaya, E.; Sobolev, N.; Tsarevskaya, N.; Becker, T.; Berastegi, A.; Bückle, C.; Che, R. Biodiversity patterns of dry grasslands in the Central Apennines (Italy) along a precipitation gradient: Experiences from the 10th EDGG Field Workshop. Bull. Eurasian Dry Grassl. Group 2018, 36, 25-41.

20. Primi, R.; Filibeck, G.; Amici, A.; Bückle, C.; Cancellieri, L.; Di Filippo, A.; Gentile, C.; Guglielmino, A.; Latini, R.; Mancini, L.D. From Landsat to leafhoppers: A multidisciplinary approach for sustainable stocking assessment and ecological monitoring in mountain grasslands. Agric. Ecosyst. Environ. 2016, 234, 118-133. [CrossRef]

21. Ruggiero, A.; Solimini, A.G.; Carchini, G. Limnological aspects of an Apennine shallow lake. Ann. Limnol. Int. J. Limnol. 2004, 40, 89-99. [CrossRef]

22. Solimini, A.G.; Bazzanti, M.; Ruggiero, A.; Carchini, G. Developing a multimetric index of ecological integrity based on macroinvertebrates of mountain ponds in central Italy. In Pond Conservation in Europe; Oertli, B., Céréghino, R., Biggs, J., Declerck, S., Hull, A., Miracle, M.R., Eds.; Springer: Dordrecht, The Netherlands, 2007; pp. 109-123.

23. Calhoun, A.J.; Mushet, D.M.; Bell, K.P.; Boix, D.; Fitzsimons, J.A.; Isselin-Nondedeu, F. Temporary wetlands: Challenges and solutions to conserving a 'disappearing'ecosystem. Biol. Conserv. 2017, 211, 3-11. [CrossRef]

24. Hunter, M.L., Jr.; Acuña, V.; Bauer, D.M.; Bell, K.P.; Calhoun, A.J.; Felipe-Lucia, M.R.; Fitzsimons, J.A.; González, E.; Kinnison, M.; Lindenmayer, D. Conserving small natural features with large ecological roles: A synthetic overview. Biol. Conserv. 2017, 211, 88-95. [CrossRef]

25. Ruggiero, A.; Solimini, A.; Carchini, G. The alternative stable state concept and the management of Apennine mountain ponds. Aquat. Conserv. Mar. Freshw. Ecosyst. 2005, 15, 625-634. [CrossRef]

26. Solimini, A.G.; Ruggiero, A.; Anello, M.; Mutschlechner, A.; Carchini, G. The benthic community structure in mountain ponds affected by livestock watering in nature reserves of Central Italy. Int. Ver. Theor. Angew. Limnol. Verh. 2000, 27, 501-505. [CrossRef]

27. Ruggiero, A.; Solimini, A.; Carchini, G. Pratica dell'alpeggio e conservazione ambientale negli stagni montani dell'Appennino Centrale. In Proceedings of the Atti del Convegno Nazionale Conservazione Dell'ambiente e Rischio Idrogeologico, Perugia, Italy, 11-12 December 2002; pp. 687-694.

28. Wissinger, S.A.; Oertli, B.; Rosset, V. Invertebrate communities of alpine ponds. In Invertebrates in Freshwater Wetlands; Batzer, D., Boix, D., Eds.; Springer: Cham, Switzerland, 2016; pp. 55-103.

29. Howell, H.J.; Mothes, C.C.; Clements, S.L.; Catania, S.V.; Rothermel, B.B.; Searcy, C.A. Amphibian responses to livestock use of wetlands: New empirical data and a global review. Ecol. Appl. 2019. [CrossRef]

30. Iannella, M.; Cerasoli, F.; Biondi, M. Unraveling climate influences on the distribution of the parapatric newts Lissotriton vulgaris meridionalis and L. italicus. Front. Zool. 2017, 14, 55. [CrossRef]

31. Iannella, M.; D'Alessandro, P.; Biondi, M. Evidences for a shared history for spectacled salamanders, haplotypes and climate. Sci. Rep. 2018, 8, 16507. [CrossRef]

32. Hayes, T.B.; Stuart, A.A.; Mendoza, M.; Collins, A.; Noriega, N.; Vonk, A.; Johnston, G.; Liu, R.; Kpodzo, D. Characterization of atrazine-induced gonadal malformations in African clawed frogs (Xenopus laevis) and comparisons with effects of an androgen antagonist (cyproterone acetate) and exogenous estrogen (17ß-estradiol): Support for the demasculinization/feminization hypothesis. Environ. Health Perspect 2006, 114, 134-141.

33. Buck, J.C.; Scheessele, E.A.; Relyea, R.A.; Blaustein, A.R. The effects of multiple stressors on wetland communities: Pesticides, pathogens and competing amphibians. Freshw. Biol. 2012, 57, 61-73. [CrossRef]

34. Patar, A.; Giri, A.; Boro, F.; Bhuyan, K.; Singha, U.; Giri, S. Cadmium pollution and amphibians-Studies in tadpoles of Rana limnocharis. Chemosphere 2016, 144, 1043-1049. [CrossRef] 
35. Ferreira, M.; Beja, P. Mediterranean amphibians and the loss of temporary ponds: Are there alternative breeding habitats? Biol. Conserv. 2013, 165, 179-186. [CrossRef]

36. Ficetola, G.F.; Rondinini, C.; Bonardi, A.; Baisero, D.; Padoa-Schioppa, E. Habitat availability for amphibians and extinction threat: A global analysis. Divers. Distrib. 2015, 21, 302-311. [CrossRef]

37. Stuart, S.N.; Chanson, J.S.; Cox, N.A.; Young, B.E.; Rodrigues, A.S.; Fischman, D.L.; Waller, R.W. Status and trends of amphibian declines and extinctions worldwide. Science 2004, 306, 1783-1786. [CrossRef] [PubMed]

38. May, R.M. Ecological science and tomorrow's world. Philos. Trans. R. Soc. B Biol. Sci. 2010, 365, 41-47. [CrossRef]

39. Best, M.L.; Welsh, J.; Hartwell, H. The trophic role of a forest salamander: Impacts on invertebrates, leaf litter retention, and the humification process. Ecosphere 2014, 5, 1-19. [CrossRef]

40. Davic, R.D.; Welsh, H.H. On the ecological roles of salamanders. Annu. Rev. Ecol. Evol. Syst. 2004, 35, 405-434. [CrossRef]

41. Salvidio, S.; Costa, A.; Crovetto, F. Individual trophic specialization in the Alpine newt increases with increasing resource diversity. Ann. Zool. Fenn. 2019, 56, 17-24. [CrossRef]

42. Vignoli, L.; Bombi, P.; D'Amen, M.; Bologna, M.A. Seasonal variation in the trophic niche of a heterochronic population of Triturus alpestris apuanus from the south-western Alps. Herpetol. J. 2007, 17, 183-191.

43. Schabetsberger, R.; Jehle, R.; Maletzky, A.; Pesta, J.; Sztatecsny, M. Delineation of terrestrial reserves for amphibians: Post-breeding migrations of Italian crested newts (Triturus c. carnifex) at high altitude. Biol. Conserv. 2004, 117, 95-104. [CrossRef]

44. Vanni, S.; Andreone, F.; Tripepi, S. Istituto Superiore per La Protezione e La Ricerca Ambientale; Anfibi d'Italia. Lanza, B., Nistri, A., Vanni, S., Eds.; Ministero dell'Ambiente e della Tutela del Territorio e del Mare: Rome, Italy, 2007; Volume 29.

45. Naviglio, L. Aspetti naturalistici del Lago Pantaniello. Nat. Montagna. 1984, 31, 49-57.

46. Ferri, V.; Di Tizio, L.; Pellegrini, M. Atlante Degli Anfibi d'Abruzzo; Ianieri-Talea: Pescara, Italy, 2007; p. 199.

47. Andreone, F.; Corti, C.; Ficetola, F.; Razzetti, E.; Romano, A.; Sindaco, R. Triturus carnifex. The IUCN Red List of Threatened Species. 2009: e.T59474A11947714. Available online: https:/www.iucnredlist.org/species/ 59474/11947714 (accessed on 5 December 2018).

48. Beebee, T.J.C.; Griffiths, R.A. The amphibian decline crisis: A watershed for conservation biology? Biol. Conserv. 2005, 125, 271-285. [CrossRef]

49. D'Amen, M.; Bombi, P. Global warming and biodiversity: Evidence of climate-linked amphibian declines in Italy. Biol. Conserv. 2009, 142, 3060-3067. [CrossRef]

50. Collins, J.P.; Crump, M.L.; Lovejoy Iii, T.E. Extinction in Our Times: Global Amphibian Decline; Oxford University Press: New York, NY, USA, 2009.

51. Solé, M.; Rödder, D. Dietary assessments of adult amphibians. In Amphibian Ecology and Conservation: A Handbook of Techniques; Oxford University Press: New York, NY, USA, 2010; pp. 167-184.

52. Oksanen, J.; Blanchet, F.G.; Friendly, M.; Kindt, R.; Legendre, P.; McGlinn, D.; Minchin, P.R.; O’Hara, R.; Simpson, G.L.; Solymos, P. 2019. Vegan: Community Ecology Package. R package version 2.5-4. Available online: https://cran.r-project.org/web/packages/vegan (accessed on 1 September 2019).

53. R Core Team. R: A Language and Environment for Statistical Computing; R Foundation for Statistical Computing: Vienna, Austria, 2017; Available online: http://www.R-project.org (accessed on 15 June 2017).

54. Nenadic, O.; Greenacre, M. Correspondence Analysis in R, with two-and three-dimensional graphics: The ca package. J. Stat. Softw. 2007, 20, 1-13.

55. Costa, A.; Salvidio, S.; Posillico, M.; Matteucci, G.; De Cinti, B.; Romano, A. Generalisation within specialization: Inter-individual diet variation in the only specialized salamander in the world. Sci. Rep. 2015, 5, 13260. [CrossRef]

56. Vignoli, L.; Bologna, M.A. Dietary patterns and overlap in an amphibian assemblage at a pond in Mediterranean central Italy. Vie Milieu-Life Environ. 2009, 59, 47-57.

57. Fasola, M.; Canova, L. Feeding habits of Triturus vulgaris, T. cristatus and T. alpestris (Amphibia, Urodela) in the northern Apennines (Italy). Ital. J. Zool. 1992, 59, 273-280.

58. Regio Decreto Legislativo. Riordinamento E Riforma Della Legislazione in Materia di Boschi E di Terreni Montani; Italy, Ed.; NORMATTIVA: Rome, Italy, 1923.

59. Buono, V.; Bissattini, A.M.; Vignoli, L. Can a cow save a newt? The role of cattle drinking troughs in amphibian conservation. Aquat. Conserv. Mar. Freshw. Ecosyst. 2019, 29, 964-975. [CrossRef] 
60. Schmutzer, A.C.; Gray, M.J.; Burton, E.C.; Miller, D.L. Impacts of cattle on amphibian larvae and the aquatic environment. Freshw. Biol. 2008, 53, 2613-2625. [CrossRef]

61. Hoverman, J.T.; Gray, M.J.; Miller, D.L.; Haislip, N.A. Widespread occurrence of ranavirus in pond-breeding amphibian populations. Eco. Health 2012, 9, 36-48. [CrossRef]

62. Badillo-Saldaña, L.M.; Ramírez-Bautista, A.; Wilson, L.D. Effects of establishment of grazing areas on diversity of amphibian communities in tropical evergreen forests and mountain cloud forests of the Sierra Madre Oriental. Rev. Mex. Biodivers. 2016, 87, 133-139. [CrossRef]

63. Moreira, L.F.; Moura, R.G.; Maltchik, L. Stop and ask for directions: Factors affecting anuran detection and occupancy in Pampa farmland ponds. Ecol. Res. 2016, 31, 65-74. [CrossRef]

64. Howard, A.; Munger, J.C. Effects of Livestock Grazing on the Invertebrate Prey Base and on the Survival and Growth of Larvae of the Columbia Spotted Frog, Rana Luteiventris; Bureau of Land Management, Idaho State Office: Boise, ID, USA, 2003.

65. Zelnik, I.; Gregorič, N.; Tratnik, A. Diversity of macroinvertebrates positively correlates with diversity of macrophytes in karst ponds. Ecol. Eng. 2018, 117, 96-103. [CrossRef]

66. Byrne, P.G.; Silla, A.J. Testing the effect of dietary carotenoids on larval survival, growth and development in the critically endangered southern corroboree frog. Zoo. Biol. 2017, 36, 161-169. [CrossRef] [PubMed]

67. Clugston, R.D.; Blaner, W.S. Vitamin A (retinoid) metabolism and actions: What we know and what we need to know about amphibians. Zoo. Biol. 2014, 33, 527-535. [CrossRef] [PubMed]

68. Szuroczki, D.; Koprivnikar, J.; Baker, R.L. Dietary antioxidants enhance immunocompetence in larval amphibians. Comp. Biochem. Physiol. Part A Mol. Integr. Physiol. 2016, 201, 182-188. [CrossRef]

69. Arribas, R.; Díaz-Paniagua, C.; Caut, S.; Gomez-Mestre, I. Stable isotopes reveal trophic partitioning and trophic plasticity of a larval amphibian guild. PLOS ONE 2015, 10. [CrossRef]

70. Hidalgo-Ruz, V.; Gutow, L.; Thompson, R.C.; Thiel, M. Microplastics in the marine environment: A review of the methods used for identification and quantification. Environ. Sci. Technol. 2012, 46, 3060-3075. [CrossRef]

71. Döring, B.; Mecke, S.; Kieckbusch, M.; O'Shea, M.; Kaiser, H. Food spectrum analysis of the Asian toad, Duttaphrynus melanostictus (Schneider, 1799) (Anura: Bufonidae), from Timor Island, Wallacea. J. Nat. Hist. 2017, 51, 607-623. [CrossRef]

72. Hu, L.; Chernick, M.; Hinton, D.E.; Shi, H. Microplastics in small waterbodies and tadpoles from Yangtze River Delta, China. Environ. Sci. Technol. 2018, 52, 8885-8893. [CrossRef]

73. De Felice, B.; Bacchetta, R.; Santo, N.; Tremolada, P.; Parolini, M. Polystyrene microplastics did not affect body growth and swimming activity in Xenopus laevis tadpoles. Environ. Sci. Pollut. Res. 2018, 25, 34644-34651. [CrossRef] [PubMed]

74. Da Costa Araújo, A.P.; de Melo, N.F.S.; de Oliveira Junior, A.G.; Rodrigues, F.P.; Fernandes, T.; de Andrade Vieira, J.E.; Rocha, T.L.; Malafaia, G. How much are microplastics harmful to the health of amphibians? A study with pristine polyethylene microplastics and Physalaemus cuvieri. J. Hazard. Mater. 2020, 382, 121066. [CrossRef] [PubMed]

(C) 2019 by the authors. Licensee MDPI, Basel, Switzerland. This article is an open access article distributed under the terms and conditions of the Creative Commons Attribution (CC BY) license (http://creativecommons.org/licenses/by/4.0/). 